Tampoma, W.P. • T. Nurmala • M. Rachmadi

\title{
Pengaruh dosis silika terhadap karakter fisiolog1 dan hasil tanaman padi (Oryza sativa L.) kultivar lokal poso (kultıvar 36-Super dan Tagolu)
}

\section{Effect of silica dosage on physiological and yield characteristic of local poso rice cultivars (cultivar 36-Super and Tagolu)}

Diterima : 17 Agustus 2017/Disetujui : 25 Agustus 2017 / Dipublikasikan : 31 Agustus 2017

CDepartment of Crop Science, Padjadjaran University

\begin{abstract}
Rice (Oryza sativa L.) is an important in Indonesia as staple food. Often, local rice cultivars are low-productivity. However, the application of silica to rice crops could optimize the growth and yield of rice. The purposes of this study were the influence of silica to physiological and yield character of local Poso rice cultivars. The experimental design used the split plot design. The first factor as the main plot consists of two treatment levels namely cultivar 36-Super and cultivar Tagolu). The second factor as subplot was consisting of 4 treatment levels, there are without silica, silica dosage $0,5 \mathrm{~L} / \mathrm{ha}$, silica dosage $1 \mathrm{~L} /$ ha and silica dosage $1.5 \mathrm{~L} / \mathrm{ha}$.

The results showed that there was no effect of interaction between cultivars and silica dosage on the physiological character and the yield. 36Super cultivar showed the best effect on dry weight of the plant $(45,08 \mathrm{~g})$ and harvest age (139,50 days after seedling) and number of panicles per hill (26,67 panicle). Cultivar Tagolu presented the best effect on the number of grains per panicle (164, 09 panicle). The silica dosage of $1 \mathrm{~L} /$ ha showed the best effect to the leaf angles $\left(31,38^{\circ}\right)$, the leaf corner $\left(18,75^{\circ}\right)$, the dry weight of the plant $(40.67 \mathrm{~g})$, the weight of grain per hill $(57.77 \mathrm{~g})$ and 1000 weights of grain $(22.48 \mathrm{~g})$. However, the treatment without silica showed earliest harvest age (131.08 day after seedling).
\end{abstract}

Keywords : Cultivar $\cdot$ Silica

Sari Padi (Oryza sativa L.) merupakan salah satu jenis tanaman yang memegang peran penting di Indonesia dalam memenuhi kebutuhan pangan.

\footnotetext{
Dikomunikasikan oleh Aep Wawan Irwan

Tampoma, W.P.1 $\cdot$ T. Nurmala ${ }^{2} \cdot$ M. Rachmadi ${ }^{2}$

1) Alumni Universitas Sintuwu Maroso Poso

2) Staf Pengajar Fakultas Pertanian Universitas Padjadjaran

Korespondensi : wtampoma@gmail.com
}

Tanaman padi kultivar lokal merupakan salah satu jenis padi yang memiliki poduktivitas rendah. Pemberian silika pada pertanaman padi dapat membantu mengoptimalkan pertumbuhan dan hasil tanaman padi. Tujuan penelitian ini adalah untuk mengetahui pengaruh dosis silika terhadap karakter fisiologi dan hasil tanaman padi (Oryza sativa L.) kultivar lokal Poso. Rancangan percobaan yang digunakan adalah Rancangan Petak Terbagi (RPT). Faktor pertama sebagai petak utama terdiri dua taraf perlakuan yaitu kultivar 36-Super dan kultivar Tagolu. Faktor kedua sebagai anak petak terdiri atas 4 taraf perlakuan yaitu tanpa silika, dosis silika $0,5 \mathrm{~L} /$ ha, dosis silika $1 \mathrm{~L} / \mathrm{ha}$ ) dan dosis silika 1,5 L/ha). Hasil penelitian menunjukkan bahwa tidak terdapat pengaruh interaksi antara kultivar dan dosis silika terhadap karakter fisiologi dan hasil. Kutivar 36-Super menghasilkan pengaruh terbaik pada bobot kering tanaman $(45,08 \mathrm{~g})$ dan umur panen $(139,50$ hari setelah semai) dan jumlah malai per rumpun $(26,67$ malai). Kultivar Tagolu meng-hasilkan pengaruh terbaik pada jumlah gabah per malai (164,09 bulir). Dosis silika $1 \mathrm{~L} / \mathrm{ha}$ menghasilkan pengaruh terbaik terhadap sudut daun $\left(31,38^{\circ}\right)$, sudut daun bendera $\left(18,75^{\circ}\right)$ bobot kering tanaman $(40,67 \mathrm{~g})$, bobot gabah per rumpun $(57,77 \mathrm{~g})$ dan bobot 1000 butir $(22,48 \mathrm{~g})$. Perlakuan tanpa silika menghasilkan pengaruh terbaik terhadap umur panen (131,08 hari setelah semai).

Kata kunci: Kultivar · Silika

\section{Pendahuluan}

Padi (Oryza sativa L.) merupakan salah satu jenis tanaman yang memegang peranan penting di Indonesia dalam memenuhi kebutuhan pangan. Hal ini menyebabkan kebutuhan akan beras terus 
mengalami peningkatan dari tahun ke tahun dan sejalan dengan peningkatan jumlah penduduk. Berbagai upaya terus dilakukan pemerintah dalam mengatasi permasalahan kebutuhan beras.

Produktivitas varietas lokal rendah bila dibandingkan dengan varietas modern, namun varietas local juga memegang peranan yang sangat penting selain sebagai penunjang ketahanan pangan nasional. Varietas lokal memiliki banyak keunggulan karena bersifat spesifik lokasi di antaranya toleran terhadap cekaman biotik dan abiotok. Varietas lokal juga banyak digunakan sebagai donor gen dalam menghasilkan suatu varietas unggul baru (Daradjat dkk., 2008).

Selain masalah varietas pemupukan juga merupakan masalah yang dihadapi dalam budidaya tamanan padi. Saat ini salah satu jenis pupuk atau unsur hara yang hampir tidak pernah diberikan atau ditambahkan ke dalam tanah pada pertanian tanaman padi adalah silika atau silikon (Si). Peran silika pada pertumbuhan dan produktivitas tanaman padi sangatlah penting. Menurut Go (1984), Si merupakan unsur yang terbanyak diserap oleh tanaman padi. Serapan $\mathrm{Si}$ oleh padi sekitar 10 kali N, 20 kali P, 6 kali K dan 30 kali Ca (Yoshida. 1985). Penambahan Si pada tanaman mempengaruhi masa jenis sel dan meningkatkan ketahanan dan kekuatan sel (Wei dkk., 2009; Sumida. 2002). Silika membantu daun untuk lebih tegak dalam pengaruh kondisi pemupukan nitrogen yang tinggi, sehingga bisa meningkatkan tingkat fotosintesis dan efesien dalam menangkap sinar matahari mencapai $10 \%$ (Nwugo dan Huerta., 2008; Song dkk., 2014; Lau dkk., 1978; Yoshida. 1985) karena daunnya mengarah ke atas, efisien dalam menggunakan air dan tidak mudah rebah karena mempunyai batang yang kuat (Yoshida. 1985).

Tujuan penelitian ini adalah untuk mengetahui pengaruh silika terhadap karakter fisiologi dan hasil tanaman padi (Oryza sativa L.) kultivar lokal Poso.

\section{Metode Penelitian}

Penelitian dilaksanakan di Kebun Percobaan Fakultas Pertanian, Universitas Padjadjaran, Kecamatan Jatinangor, Kabupaten Sumedang, Provinsi Jawa Barat dengan ketingggian tempat $700 \mathrm{~m}$ dpl. Penelitian dilaksanakan pada bulan Agustus 2016 sampai dengan bulan Januari 2017.

Bahan yang digunakan dalam penelitian adalah kultivar lokal (36-Super dan Tagolu), pupuk Silika cair $\left(\mathrm{Si}(\mathrm{HO})_{4} 13,56 \%\right)$, pupuk Urea $250 \mathrm{~kg} / \mathrm{ha}$, pupuk $\mathrm{KCl} 50 \mathrm{~kg} / \mathrm{ha}$, pupuk SP-36 $75 \mathrm{~kg} / \mathrm{ha}$.

Rancangan percobaan yang digunakan dalam penelitian ini adalah menggunakan Rancangan Petak Terbagi (RPT) yang terdiri atas dua faktor. Faktor pertama sebagai petak utama terdiri dua taraf perlakuan yaitu kultivar 36Super, dan kultivar Tagolu. Faktor ke dua sebagai anak petak terdiri atas empat taraf perlakuan yaitu tanpa silika, dosis silika 0,5 L/ha, dosis silika $1 \mathrm{~L} / \mathrm{ha}$ ) dan dosis silika 1,5 L/ha.

Pelaksanaan penelitian meliputi penyiapan media tanam, persemaian, penanaman, penyulaman, pemupukan, pengendalian gulma, pengeloaan air, pengendalian hama dan penyakit, pengamatan dan panen.

Pengamatan dilakukan terhadap variabel karakter fisiologi dan hasil. karakter fisiologi meliputi sudut daun, sudut daun bendera, bobot kering tanaman, laju asimilasi bersih dan laju pertumbuhan relatif. Pengamatan hasil meliputi umur berbunga, umur panen, jumlah malai per rumpun, jumlah gabah per malai, persentase gabah isi, bobot gabah per rumpun dan bobot 1000 butir.

Data hasil penelitian dianalisis dengan analisis sidik ragam pada taraf kepercayaan 95\% berdasarkan perhitungan rancangan petak petak terbagi menggunkan SPSS versi 17.0.

\section{Hasil dan Pembahasan}

Rekapitulasi Analisis Sidik Ragam. Hasil analisis sidik ragam pada taraf 95\% $(0,05)$ menunjukkan bahwa tidak terdapat pengaruh interaksi antara kultivar dan silika. Kultivar menmberikan pengaruh nyata terhadap variabel bobot kering tanaman, umur panen, jumlah malai per rumpun dan jumlah gabah per malai. perlakuan dosis silika memberikan pengaruh nyata terhadap variabel suduk daun ke-2 dan ke-3, sudut daun bendera, bobot kering tanaman, umur berbunga, umur panen, bobot gabah per rumpun dan bobot 1000 butir.

Sudut Daun. Tabel 2 menunjukan bahwa meskipun kultivar tidak berpengaruh terhadap sudut daun, kultivar 36-Super relatif memiliki sudut daun yang lebih kecil dibandingkan dengan kultivar Tagolu. Dosis silika $1 \mathrm{~L} / \mathrm{ha}$ memberikan sudut daun $\left(31,38^{\circ}\right)$ dan sudut daun bendera $\left(18,75^{\circ}\right)$ terkecil dibandingkan 
dengn perlakuan silika lainnya. Besaran sudut daun menggambarkan distribusi radiasi cahaya matahari ke kanopi tanaman. Sudut daun $<45^{\circ}$ merupakan kritria daun tegak, sehingga sudut daun ke-2 dan ke-3 dan sudut daun bendera kultivar 36-Super dan kultivar Tagolu tergolong tegak. Kondisi daun seperti ini dapat meningkatkan fotosintesis dan potensi peningkatan hasil. Lu dkk. (2010) menyatakan bahwa struktur kanopi mempengaruhi hasil tanaman.

Tabel 1.Rekapitulasi Analisis Sidik Ragam

\begin{tabular}{lccc}
\hline \hline \multicolumn{1}{c}{ Parameter } & $\begin{array}{c}\text { Kultivar } \\
\text { (A) }\end{array}$ & $\begin{array}{c}\text { Silika } \\
\text { (B) }\end{array}$ & $\begin{array}{c}\text { Interak } \\
\text { si A x B }\end{array}$ \\
\hline Sudut daun bendera & tn & $*$ & tn \\
Sudut daun ke-2 dan ke-3 & tn & $*$ & tn \\
Bobot kering tanaman & $*$ & $*$ & tn \\
Laju asimilasi bersih & tn & tn & tn \\
Laju pertumbuhan relatif & tn & tn & tn \\
Umur berbunga & tn & $*$ & tn \\
Umur panen & $*$ & $*$ & tn \\
Jumlah malai per & $*$ & tn & tn \\
rumpun & $*$ & tn & tn \\
Jumlah gabah permalai & $*$ & $*$ & tn \\
Bobot gabah per rumpun & tn & $*$ & tn \\
Bobot 1000 butir & tn &
\end{tabular}

Keterangan : Kesimpulan analisis berdasarkan hasil nilai F yang siknifikan pada taraf 0,05 (95\%), * = berpengaruh nyata, $\mathrm{tn}=$ tidak nyata

Tabel 2. Pengaruh Kultivar dan Dosis Silika terhadap Sudut Daun dan Sudut Daun Bendera Padi (Oryza sativa L.) Kultivar Lokal Poso.

\begin{tabular}{lcc}
\hline \hline \multicolumn{1}{c}{ Perlakuan } & $\begin{array}{c}\text { Sudut Daun } \\
(\mathbf{(})\end{array}$ & $\begin{array}{c}\text { Sudut Daun } \\
\text { Bendera } \\
(\mathbf{0})\end{array}$ \\
\hline $\begin{array}{l}\text { Faktor Petak Utama } \\
\text { Kultivar 36-Super }\end{array}$ & 33,81 & 20,54 \\
Kultivar Tagolu & 36,67 & 21,88 \\
Faktor Anak Petak & & \\
Tanpa Silika & $39,42 \mathrm{~b}$ & $24,00 \mathrm{~b}$ \\
Dosis Silika 0,5 L/ha & $35,25 \mathrm{ab}$ & $21,58 \mathrm{ab}$ \\
Dosis Silika 1 L/ha & $31,38 \mathrm{a}$ & $18,75 \mathrm{a}$ \\
Dosis Silika 1,5 L/ha & $34,92 \mathrm{ab}$ & $20,50 \mathrm{ab}$ \\
\hline \hline
\end{tabular}

Keterangan : Angka yang diikuti huruf yang sama pada baris yang sama tidak berbeda nyata berdasarkan uji Duncan taraf 5\%

Menurut Lian (1996) dan Okamoto (1990) bahwa pemberian silika dapat membantu daun tanaman lebih tegak dibandingkan tanaman tanpa silika. Posisi daun tegak akan memaksimalkan tanaman dalam menyerap sinar matahari secara maksimal dan dapat meningkatkan fotosintesis hingga 10\% (Yoshida. 1981).

Bobot Kering Tanaman. Tabel 3 menunjukkan bahwa kultivar 36-Super menghasilkan bobot kering tanaman $(45,08 \mathrm{~g})$ lebih besar dan berbeda dengan kultivar Tagolu. Dosis silika 1 L/ha menghasilkan bobot kering tanaman lebih besar dan berbeda dengan perlakuan tanpa silika namun tidak berbeda dengan perlakuan onsentrasi silika 0,5 dan $1,5 \mathrm{~L} /$ ha.

Bobot kering tanaman yang besar menggambarkan penumpukan hasil fotosintat yang besar. Yoshida (1981) menyatakan bahwa bertambahan bobot kering tanaman dipengaruhi oleh tingkat fotosintesis bersih, sudut daun, luas daun dan jumlah anakan. Bobot kering tanaman merupakan akibat dari efisiensi penyerapan dan pemanfaatan radiasi matahari secara maksimum selama pertumbuhan (Gardner dkk., 1991). Hal ini menunjukkan bahwa pemberian silika dapat meningkatkan hasil fotosintesis tanaman dan sejalan dengan besar sudut daun yng terbentuk.

Tabel 3. Pengaruh Kultivar dan Dosis Silika terhadap Bobot Kering Tanaman, Laju Asimilasi Bersih dan Laju Pertumbuhan Relatif Padi (Oryza sativa L.) Kultivar Lokal Poso.

\begin{tabular}{lccc}
\hline \hline \multicolumn{1}{c}{ Perlakuan } & $\begin{array}{c}\text { Bobot } \\
\text { Kering } \\
\text { Tanaman } \\
\mathbf{( g )}\end{array}$ & $\begin{array}{c}\text { Laju } \\
\text { Asimilasi } \\
\text { Bersih } \\
\mathbf{( g / d ^ { 2 } /} \\
\text { minggu) }\end{array}$ & $\begin{array}{c}\text { Laju } \\
\text { Pertum- } \\
\text { buhan } \\
\text { Relatif } \\
\text { (g/ } \\
\text { minggu) }\end{array}$ \\
\hline Petak Utama & & & \\
Kultivar 36-Super & $45,08 \mathrm{a}$ & 2,41 & 0,21 \\
Kultivar Tagolu & $29,68 \mathrm{~b}$ & 1,00 & 0,28 \\
Anak petak & & & \\
Tanpa Silika & $33,45 \mathrm{~b}$ & 1,67 & 0,22 \\
Dosis Silika 0,5 L/ha & $37,15 \mathrm{ab}$ & 1,71 & 0,23 \\
Dosis Silika 1 L/ha & $40,67 \mathrm{a}$ & 1,75 & 0,24 \\
Dosis Silika 1,5 L/ha & $38,23 \mathrm{a}$ & 1,62 & 0,24 \\
\hline \hline
\end{tabular}

Keterangan : Angka yang diikuti huruf yang sama pada baris yang sama tidak berbeda nyata berdasarkan uji Duncan taraf 5\%

Laju Asimilasi Bersih. Pada Tabel 3 menunjukkan bahwa meskipun tidak berpengaruh nyata, kultivar 36-Super dan dosis silika 1 L/ha relatif menghasilkan laju asimilasi bersih (LAB) yang lebih besar. Peningkatan LAB sejalan dengan peningkatan bobot kering tanaman. LAB merupakan ukuran efisiensi fotosintesis daun, dimana nilai tertinggi LAB yaitu saat tanaman masih kecil karena sebagian daun terkena sinar matahari dan mengalami penurunan saat tanaman memasuki masa pengsian biji karena sebagian besar daun terlindungi oleh daun bagian atas (Gardner dkk., 1991).

Menurut Gardner (1991) bahwa LAB merupakan gambaran dari laju penimbunan bobot 
kering tanaman per satuan waktu dan juga ukuran efisiensi fotosintesis daun. Menurut Lian (1996) silika berperan bagi tanaman dalam kondisi kekeringan adalah meningkatkan fotosintesi dan aktivitas akar, menekan laju transpirasi dan memperbaiki membran plasma.

Laju Pertumbuhan Relatif. Laju pertumbuhan relatif (LPR) menunjukkan peningkatan berat kering dalam suatu interval waktu (Gardner, 1991). Setiap genotip tanaman memiliki nilai LPR yang berbeda-beda karena ditentukan oleh bentuk kanopi daun (Horie, 2001; Yoshida, 1981). Penambahan berat kering tanaman dan luas daun tanaman akan mengakibatkan penurunan LPR (Gardner, 1991) hal ini disebabkan karena sebagian besar daun bagian terlnaungi sehingga tidak maksimal dalam melakukan fotosintesis. LPR akan mempengaruhi peningkatan kapasitas source yang dapat memenuhi kebutuhan kapasitas sink sehingga akan berpengaruh terhadap hasil.

Umur Berbunga. Pada Tabel 4 menunjukkan bahwa meskipun tidak berpengaruh nyata, kultivar 36-Super menghasilkan umur berbunga relatif lebih cepat dibandingkan dengan kultivar Tagolu. Perlakuan tanpa silika menghasilkan umur berbunga lebih cepat (109,00 hss) dan berbeda dengan perlakuan dosis silika 1,5 L/ha namun tidak berbeda dengan perlakuan dosis silika 0,5 dan $1 \mathrm{~L} / \mathrm{ha}$. Perbedaan umur berbunga menunjukkan respon tanaman yang berbeda terhadap kondisi lingkungan yang berbeda. Selain itu, umur berbunga ditentukan oleh lamanya fase pertumbuhan vegetatif (Makarim dan Suhartatik, 2009) sehingga semakin lama fase pertumbuhan vegetatif, maka umur berbunga akan semakin lama.

Umur Panen. Pada tabel 4 menunjukkan bahwa kultivar menghasilkan umur panen lebih cepat (139 HSS) dibandingkan dengan kultivar Tagolu. Perlakuan tanpa silika menghasilkan umur panen lebih cepat (131,08 hss) dan berbeda dengan perlakuan dosis silika 1,5 L/ha namun tidak berbeda dengan perlakuan dosis silika 0,5 dan $1 \mathrm{~L} /$ ha. Umur panen berkaitan dengan umur berbunga (Miswarti dkk., 2014) dimana semakin cepat umur berbunga maka umur panen akan semakin cepat dan demikian sebaliknya.

Jumlah Malai per Rumpun. Jumlah malai per rumpun berdasarkan Tabel 5 menunjukkan bahwa pengaruh kultivar 36-Super berbeda nyata dengan kultivar Tagolu dengan jumlah malai per rumun 26,67 malai. Karakteristik suatu tanaman yang ideal dengan tipe malai berat memiliki sink besar dan source cukup yaitu jumlah malai efektif per rumpun adalah 12-15 dan jumlah gabah 180-240 (Jun dkk., 2003; Jun dkk., 2006). Perlakuan dosis silika tidak perpengaruh, namun dosis silika $1 \mathrm{~L} /$ ha menghasilkan julmlah malai per rumpun (21,56 malai) relatif lebih tinggi dibandingkan dengan perlakuan silika lainnya..

Tabel 4. Pengaruh Kultivar dan Dosis Silika terhadap Umur Berbunga dan Umur Panen Padi (Oryza sativa L.) Kultivar Lokal Poso.

\begin{tabular}{lcc}
\hline \hline \multicolumn{1}{c}{ Perlakuan } & $\begin{array}{c}\text { Umur } \\
\text { Berbunga } \\
\text { (HSS) }\end{array}$ & $\begin{array}{c}\text { Umur } \\
\text { Panen } \\
\text { (HSS) }\end{array}$ \\
\hline Petak Utama & & \\
Kultivar 36-Super & 107,29 & $139,50 \mathrm{a}$ \\
Kultivar Tagolu & 112,75 & $145,33 \mathrm{~b}$ \\
Anak petak & & \\
Tanpa Silika & $109.00 \mathrm{a}$ & $131.08 \mathrm{a}$ \\
Dosis Silika 0,5 L/ha & $109.83 \mathrm{a}$ & $132.42 \mathrm{a}$ \\
Dosis Silika 1 L/ha & $110.17 \mathrm{ab}$ & $133.00 \mathrm{ab}$ \\
Dosis Silika 1,5 L/ha & $111.08 \mathrm{~b}$ & $133.58 \mathrm{~b}$ \\
\hline \hline
\end{tabular}

Keterangan : Angka yang diikuti huruf yang sama pada baris yang sama tidak berbeda nyata berdasarkan uji Duncan taraf 5\%

Tabel 5. Pengaruh Kultivar dan Dosis Silika terhadap Jumlah Malai per Rumpun dan Jumlah Gabah Isi Padi (Oryza sativa L.) Kultivar Lokal Poso

\begin{tabular}{lcc}
\hline \hline \multicolumn{1}{c}{ Perlakuan } & $\begin{array}{c}\text { Jumlah Malai } \\
\text { per Rumpun } \\
\text { (malai) }\end{array}$ & $\begin{array}{c}\text { Jumlah } \\
\text { Gabah per } \\
\text { Malai } \\
\text { (butir) }\end{array}$ \\
\hline Petak Utama & & \\
Kultivar 36-Super & $26,67 \mathrm{a}$ & $132,17 \mathrm{~b}$ \\
Kultivar Tagolu & $13,89 \mathrm{~b}$ & $164,69 \mathrm{a}$ \\
Anak petak & & \\
Tanpa Silika & 18.81 & 136.53 \\
Dosis Silika 0,5 L/ha & 20.13 & 142.75 \\
Dosis Silika 1 L/ha & 21.56 & 164.18 \\
Dosis Silika 1,5 L/ha & 20.60 & 150.28 \\
\hline Re
\end{tabular}

Keterangan : Angka yang diikuti huruf yang sama pada baris yang sama tidak berbeda nyata berdasarkan uji Duncan taraf 5\%

Jumlah Gabah per Malai. Panjang malai berdasarkan Tabel 5 menunjukkan bahwa pengaruh kultivar Tagolu berbeda nyata dengan kultivar 36-Super dengan panjang malai 27,33 $\mathrm{cm}$. sedangkan perlakuan silika tidak berpengaruh terhadap panjang malai. Malai yang besar dengan jumlah gabah per malai lebih 
banyak akan meningkatkan kepadatan malai (Zang dkk., 2010). Ukuran panjang malai dibedakan menjadi tiga ukuran, yaitu ukuran pendek $(<20 \mathrm{~cm})$, ukuran sedang $(20-30 \mathrm{~cm})$ dan ukuran panjang $(>30 \mathrm{~cm})$. hal ini menujukan bahwa varietas yang dipakai dalan percobaan ini adalah kelompok malai sedang.

Bobot Gabah per Rumpun. Pada tabel 6 menujukkan bahwa meskipun tidak berpengaruh nyata, kultivar 36-Super relatif menghasilkan bobot gabah per rumpun lebih besar dibandingkan dengan kultivar Tagolu Perlakuan dosis silika $1 \mathrm{~L} /$ ha menghasilkan bobot gabah per rumpun $(57,77 \mathrm{~g})$ lebih tinggi tetapi tidak berbeda dengan dosis silika 0,5 dan $1,5 \mathrm{~L} / \mathrm{ha}$. Besarnya bobot gabah per rumpun sejalan dengan jumlah malai per rumpun, bobot kering tanaman dan laju asimilasi bersih kultivar 36-Super yang tinggi. Hasil tergolong masih rendah dan diduga disebabkan rendahnya hasil asimilasi pada sink selama fase generatif. Menurut Jun dkk. (2006) dan Yuan (2001) menyatakan bahwa tipe ideal tanaman dengan potensi hasil tinggi adalah tanaman yang dapat menghasilkan bobot gabah $5 \mathrm{~g}$ per malai atau setara $60-75 \mathrm{~g}$ per rumpun, bobot 1000 butir 28-30 g (Peng dan Khush, 2003).

Tabel 6. Pengaruh Kultivar dan Dosis Silika terhadap Bobot Gabah per Rumpun dan Bobot 1000 Butir Padi (Oryza sativa L.) Kultivar Lokal Poso.

\begin{tabular}{lcc}
\hline \hline \multicolumn{1}{c}{ Perlakuan } & $\begin{array}{c}\text { Bobot Gabah } \\
\text { per Rumpun } \\
(\mathbf{g})\end{array}$ & $\begin{array}{c}\text { Bobot 1000 } \\
\text { Butir } \\
\text { (g) }\end{array}$ \\
\hline Petak Utama & & \\
Kultivar 36-Super & 56,68 & 21,50 \\
Kultivar Tagolu & 52,34 & 22,19 \\
Anak petak & & \\
Tanpa Silika & $50.46 \mathrm{~b}$ & $21.38 \mathrm{~b}$ \\
Dosis Silika 0,5 lt/ha & $54.35 \mathrm{ab}$ & $21.66 \mathrm{~b}$ \\
Dosis Silika 1 lt/ha & $57.77 \mathrm{a}$ & $22.48 \mathrm{a}$ \\
Dosis Silika 1,5 lt/ha & $55.47 \mathrm{a}$ & $21.86 \mathrm{ab}$ \\
\hline \hline
\end{tabular}

Keterangan : Angka yang diikuti huruf yang sama pada baris yang sama tidak berbeda nyata berdasarkan uji Duncan taraf 5\%

Bobot 1000 Butir. Bobot 1000 butir berdasarkan tabel 6 menunjukkan bahwa meskipun kultivar tidak berpengaruh nyata, namun kultivar Tagolu relatif mengasilkan bobot 1000 butir lebih tinggi dibandingkan dengan kultivar 36-Super. Perkuan dosis silika 1
L/ha mengasilkan bobot 1000 butir lebih tingggi $(22,48$ g) namun tidak berbeda dengan perlakuan dosis silika 1,5 L/ha. Gadrner dkk. (1991) mengatakan berat biji dipengaruhi oleh fotosintesis yang terjadi setelah pembungaan.

\section{Kesimpulan}

Berdasarkan hasil penelitian dan pembahasan dapat disimpulkan bahwa:

1. Tidak terdapat pengaruh interaksi antara kultivar dan dosis silika terhadap karakter fisiologi dan hasil padi (Oryza sativa L.) kultivar lokal Poso.

2. Kutivar 36-Super menghasilkan pengaruh terbaik terhadap bobot kering tanaman $(45,08 \mathrm{~g})$ dan umur panen $(139,50 \mathrm{hss})$ dan jumlah malai per rumpun (26,67 malai). Kultivar Tagolu menghasilkan pengaruh terbaik pada jumlah gabah per malai $(164,09$ bulir).

3. Dosis silika $1 \mathrm{~L} /$ ha menghasilkan pengaruh terbaik terhadap sudut daun $\left(31,38^{\circ}\right)$, sudut daun bendera $\left(18,75^{\circ}\right)$ bobot kering tanaman $(40,67 \mathrm{~g})$, bobot gabah per rumpun $(57,77 \mathrm{~g})$ dan bobot 1000 butir (22,48 g). Perlakuan tanpa silika menghasilkan pengaruh terbaik terhadap umur panen $(131,08$ hari setelah semai).

\section{Saran}

1. Untuk mendapatkan hasil yang maksimal, perlu dilakukan penambahan silika dengan dosis silika $1 \mathrm{~L} / \mathrm{ha}$.

2. Perlu dilakukan kajian lebih lanjut terhadap interval dan atau waktu aplikasi silika berdasarkan fase pertumbuhan tanaman padi untuk mendapatkan kesesuaian aplikasi dosis silika $1 \mathrm{~L} /$ ha pada tanaman padi.

\section{Ucapan Terima Kasih}

1. Ucapan terima kasih diampaikan kepada Prof. Dr. Ir. Hj. Tati Nurmala dan Dr. Ir. Meddy Rachmadi, MS yang telah membantu penulis utama dalam menyelesaikan penelitian dan penyusunan karya ilmiah ini.

2. Lembaga Pengelola Dana Pendidikan (LPDP) yang telah membantu dan mendukung melalui bantuan dana penelitian. 


\section{Daftar Pustaka}

Daradjat, A.A., Setyono, A., Makarim A.K dan hasanuddin, A. 2008. Padi. Inovasi Teknologi Produksi. Jakarta: Balai Besar Penelitian Tanaman Padi.

Gardner, P.F., Pearce, B.R dan Mitchel. 1991. Fisiologi Tanaman Budidaya. Jakarta: Universitas Indonesia.

Go B. H. 1984. Pemupukan Tanaman Padi Gogo. Prasarana Raker. Padi Tanah Kering. Kaliurang 6-8 Juli 1984.

Horie, T. 2001. Increasing Yield Potential In Irrigated Rice; Breaking The Yield Barrier. In: Peng S, Hardy. B. (Eds). Rice research for food security and poverty alleviation. International Rice Research Institute. Los Banos. Philippines. Pp. 3-25.

Jun MA, Zhu Q S, Wen-bo MA, Tian YH, Yang JC, Zhou KD. 2003. Studies on the photosynthetic characteristics and assimilate's accumulation and transformation in heavy panicle type of rice. Scientia Agricultura Sinica $36: 375$ - 381 .

Jun MA,Wen-bo MA, Ming DF, Yang SM, Zhu QS. 2006. Characteristics of rice plant with heavy panicle. Agricultural Sciences in China 5(12): 911 - 918.

Lau, E.M., Goldoftas, V.D and Baldwin, P (1978) Structure and localization of silica in the leaf and internodal epidermal system of the marsh grass Phragmites australis. Canadian Journal Botany 56, 1696-1701.

Lian, S. 1996. "Silica Fertilization Of Rice", in the fertility of paddy soils and fertilizer application for rice. Fftc-Aspac. TaipehTaiwan. P 197-221.

Lu, Cg., Ning, H., Yao, Km., Xia, S.J and Qi, Qm. 2010. Plant type and its effects on canopy structure at heading stage in various ecological areas for a two-line hybrid rice combination, liangyoupeijiu. Rice Science. 17(3) : 235-242

Makarim, A.K dan Suhartatik, E. 2009. Morfologi Dan Fisiologi Tanaman Padi. Publikasi Balai Besar Penelitian Tanaman Padi. Hal : 295-329.
Nwugo, C.C. and Huerta, A.J. 2008. Effects of silicon nutrition on cadmium uptake, growth and photosynthesis of rice plants exposed to low-level cadmium. Plant Soil. 311, 73-86.

Okamoto, Y. 1990. Physiological studies on the effects of silisic acid upon rice plant. xi. effects of various amounts of silica acid supply on the growth of rice plant and essentiality of silicon (In Japanese English Summary). Proc. Of The Crop Sci. Soc. Of Japan. 39:151-155.

Peng, S, and Khush G.S. 2003. Four decades of breeding for varietal improvement of irrigated lowland rice In The International Rice Research Institute. Plant Prod. Sci. 6 : 157-164.

Song, A., Li, P., Fan, F., Li, Z and Liang, Y. 2014. The effect of silicon on photosynthesis and expression of its relevant genes in rice (Oryza sativa L.) under high-zinc stress. PLoS ONE 9(11): e113782. doi:10.1371/ journal.pone. 0113782.

Sumida, H. 2002. Plant Available Silicon in Paddy Soil. National agricultural research center for Tohoku Region Omagari. Second Silicon in Agriculture Conference. Tsuruoka, Yamagata. Japan. 21: 43-49.

Wei C, Zhang Y, Guo J, Han Y, Yang X, Yuan J. 2009. Efects of silica nanoparticles on growth and photosynthetic pigment contents of Scenedesmus obliquus. Journal of Environmental Sciences 2010, 22(1) 155-160.

Yoshida, S. 1981. Fundamentals of rice crop science. International Rice Research Institut. Manila.

Yoshida, S. 1985. The physiology of silicon in rice. Fftc-Aspac. Techn. Bull. 25:1-27.

Yuan L. 2001. Breeding of super hybrid rice. in: peng $s$, hardy. $b$. (eds). rice research for food security and poverty alleviation. International Rice Research Institute. Los Banos, Philippines. Pp. 143-149.

Zhang, H., Tan, G.I., Xue, Yg., Liu, L.J and Yang, J.C. 2010. Changes in grain yield and morphological and physiological characteristics during 60-year evolution of japonica rice cultivars in jiangsu. Acta Agron Sin. 36(1) : 133-140. 